\title{
THE INFLUENCE OF SATISFACTION, TRUST AND PRICE OF CONSUMER LOYALTY ON GREEN PRODUCT (Case in Kandang Village Society of Bengkulu city, which have been using Energy Saving Lighting Products)
}

\author{
Rina Suthia Hayu \\ Program Studi Manajemen Fakultas Ekonomi dan Bisnis Universitas Bengkulu
}

\begin{abstract}
The increasing concern for human health and environmental sustainability, has made the companies to innovate their products into environmentally friendly products. Loyalty became the goal of marketing strategies that can be built with satisfaction, trust and price. This research aims to analyze The influence of Satisfaction, Trust and Price of Consumer Loyalty on Green Product (Case in Kandang Village Society of Bengkulu city, which have been using Energy Saving Lighting Products).The data used are primary data, sample collection method used purposive sampling with the number of respondents to 120 people, but only 102 that could be incorporated into the analysis due to lack of completeness of the respondents in its response. The analytical method used is multiple linear regression approach with the help of the program Statistical Product and Service Solutions (SPSS) version 16.0. The results of this research found partially from the calculation of the coefficients obtained by the research for satisfaction variable t provide significant value of 0.240 , the trust provide significant value for 0000, prices provide significant value for 0000. Because $t$ count on the satisfaction variable value significantly greater than 0.05 , which indicates partial satisfaction variables have no effect on consumer loyalty, while for trust and price variables as significant value $0.000<0.05$, which shows in partial trust and influence consumer loyalty energy savingt lighting products. From the calculation of the $F$ test that examines the effect of simultaneously be known $F$ calculated for the variables of satisfaction, trust, loyalty and the price is equal to 26,750 with a significant value of $0.000 \leq 0.05$ then this indicates that Satisfaction, Trust, and price simultaneously have a positive effect on consumer loyalty. The conclusion of this study are the variable of satisfaction has effect on loyalty consumers, but not significant, while trust and price, have an effect on consumer loyalty.
\end{abstract}

Keywords: Satisfaction, Trust, Price, Costumer Loyalty and Green product,

\section{PENDAHULUAN}

\section{Latar Belakang}

Isu pemanasan global telah menjadi pembahasan komunitas internasional. Sejak beberapa dekade terakhir kesadaran masyarakat dunia akan pentingnya pelestarian lingkungan semakin meningkat, peningkatan ini dicetuskan oleh adanya kekhawatiran besar kemungkinan terjadinya bencana lingkungan hidup yang mengancam, bukan hanya kesehatan, namun bahkan sampai pada kelangsungan hidup manusia dan keturunannya. Band (dalam Nasution, 2005) mengatakan bahwa kepuasan tercapai ketika kualitas memenuhi dan melebihi harapan, keinginan dan 
kebutuhan konsumen. Sebaliknya, bila kualitas tidak memenuhi dan melebihi harapan, keinginan dan kebutuhan konsumen maka kepuasan tidak tercapai. Konsumen yang tidak puas terhadap barang atau jasa yang dikonsumsinya akan mencari perusahaan lain yang mampu menyediakan kebutuhannya.

Lampu hemat energi adalah lampu yang populer digunakan di Indonesia dari kota besar sampai pelosok pedesaan semua sudah menggunakan lampu hemat energi. Dulu beberapa tahun yang lalu di pedesaan masih menggunakan lampu bohlam pijar yang berwarna kuning namun sekarang jika anda menjelajahi pedesaan maka lampu yang dipakai adalah lampu hemat energi. Ada ratusan merek lampu hemat energi yang beredar di pasaran baik merek lokal, merek China ataupun merek Eropa. Diantara merek lampu hemat energi yang menonjol di Indonesia adalah lampu Philips, lampu Osram, lampu Hori, lampu Cosmos dan lampu Sinyoku. (http://www.elektroindonesia.com)

Kepuasan yang timbul akan menciptakan persepsi yang positif dari kepercayaan konsumen terhadap merek yang akan menciptakan citra merek yang baik pula. Kesan terhadap suatu merek yang muncul dalam ingatan konsumen cenderung meningkat seiring dengan semakin tingginya tingkat pengalaman konsumen dalam penggunaan produk dengan merek tersebut.

Kepuasan akan green product yang pernah digunakan akan membuat konsumen untuk tetap menggunakan produk hijau, akan tetapi faktanya sering kali kita menjumpai suatu green product selalu memiliki harga jual yang jauh lebih tinggi daripada produk non green product, hal inilah yang sering kali membuat konsumen enggan untuk membeli green product atau pun melakukan pembelian ulang terhadap green product yang sama.

Ferdinand (2006) menjelaskan bahwa harga merupakan salah satu variable penting dalam pemasaran, dimana harga dapat mempengaruhi pelanggan dalam mengambil keputusan untuk membeli suatu produk, karena berbagai alasan. Alasan ekonomis akan menunjukkan bahwa harga yang rendah atau harga yang selalu berkompetisi merupakan salah satu pemicu penting untuk meningkatkan kinerja pemasaran, tetapi alasan psikologis dapat menunjukkan bahwa harga justru merupakan indikator kualitas dan karena itu dirancang sebagai salah satu instrumen penjualan sekaligus sebagai instrumen kompetisi yang menentukan. Berdasarkan hasil pra survei yang dilakukan pada tanggal 10 - 11 januari 2014 terhadap masyarakat yang telah menggunakan lampu hemat energi yang berlokasi di Kelurahan Kandang, Kota Bengkulu menyatakan bahwa mereka telah menggunakan lampu hemat energi dan loyal terhadap satu merek namun sebagian masyarakat mengaku telah menggunakan lampu hemat energi dengan berbagai merek. Hal ini terjadi dikarenakan tingkat kepuasan konsumen akan penggunaan lampu hemat energi yang berbeda-beda dan kepercayaan akan terhadap satu merek produk yang masih rendah.

Selain kelebihan yang diberikan produk, Harga yang bersaing antar merek produk pun di akui konsumen sebagai dasar pemilihan produk sehingga sebagian besar konsumen tidak terikat terhadap satu jenis merek produk saja. Berdasarkan hal tersebut maka penulis tertarik untuk mengetahui apakah yang mempengaruhi tingkat loyalitas pelanggan terhadap green product khususnya pada penggunaan lampu hemat energi. Untuk menjawab semua itu menurut peneliti hal yang perlu dikaji adalah bagaimanakah sesungguhnya penilaian konsumen akan produk yang memperhatikan aspek lingkungan bila dipandang dari tingkat pengaruh kepuasan, 
kepercayaan dan harga dalam mempengaruhi loyalitas konsumen pada green product.

\section{TINJAUAN PUSTAKA}

\section{Green Product}

Kasali (2009) mendefinisikan, produk hijau (Green product) adalah produk yang tidak berbahaya bagi manusia dan lingkungannya, tidak boros sumber daya, tidak menghasilkan sampah berlebihan, dan tidak melibatkan kekejaman pada binatang. Selanjutnya, Nugrahadi (2002) mengemukakan, produk hijau (green product) adalah produk yang berwawasan lingkungan. Suatu produk yang dirancang dan diproses dengan suatu cara untuk mengurangi efek-efek yang dapat mencemari lingkungan, baik dalam produksi, pendistribusian dan pengkonsumsianya. Hal ini dapat dikaitkan dengan pemakaian bahan baku yang dapat didaur ulang. Ottman (2006) mendefinisikan green product are typically durable, nontoxic, made from recycled materials or minimally packaged (produk hijau biasanya tahan lama, tidak beracun, terbuat dari bahan daur ulang).

\section{Karakteristik Green Product}

Karakteristik produk yang dianggap sebagai Green Product sebagaimana dikemukakan oleh US Federal Trade Commision dalam Lanasier (2002) adalah (a) Produk yang menggunakan bahan non toxic, (b) Produk tidak mengandung bahan yang dapat merusak lingkungan, (c) Tidak melakukan uji produk yang melibatkan binatang apabila tidak betul-betul diperlukan, (d) Selama penggunaanya tidak merusak lingkungan, (e) Menggunakan kemasan yang sederhana atau menyediakan produk isi ulang, (f) Memiliki daya tahan penggunaan yang lama dan (g) Mudah diproses ulang setelah pemakaian. Karakteristik tersebut didefenisikan setelah banyak perusahaan yang menyalahgunakan pengertian dari produk hijau ini, yaitu menggunakan istilah produk lingkungan bagi produk yang kemasannya dapat didaur ulang hanya pada kondisi tertentu.

Beberapa istilah yang sering disalah gunakan adalah Biodegradabledigunakan pada produk yang belum tentu dapat diproses pada waktu yang ditentukan, Environmentally safe dan Environtmentaly friendly aman untuk lingkungan. Menurut Kotler dalam Lanasier (2002: 91), environmentalism dapat didefenisikan sebagai suatu gerakan yang terorganisasi dari sekumpulan konsumen, pelaku bisnis dan lembaga pemerintah dalam rangka melindungi dan meningkatkan kualitas lingkungan. Kelestarian lingkungan menurut Kotler adalah pendekatan manajemen yang melibatkan pengembangan strategi selain dapat menghasilkan profit bagi perusahaan juga tetap dapat bertanggung jawab terhadap lingkungan. Oleh sebab itu, perusahaan harus melakukan langkah-langkah tanggung jawab sosialnya kepada konsumen dengan mengiklankan produknya yang menunjukkan kepekaan mereka terhadap lingkungan, yaitu dengan menekankan bahwa produk yang dihasilkan perusahaannya menggunakan kemasan yang sederhana, memberikan dampak limbah yang minimal, lebih aman bagi lingkungan dan dapat di daur ulang. 


\section{Customer Loyalty}

Menurut Kotler dan Amstrong (2001), bahwa loyalitas berasal dari pemenuhan harapan atau harapan konsumen, sedangkan ekspektasi sendiri berasal dari pengalaman pembelian terdahulu oleh konsumen, opini dari teman dan kerabat, janji atau informasi dari pemasar atau pesaing. Tjiptono (2000) berpendapat bahwa loyalitas adalah situasi dimana konsumen bersikap positif terhadap produk atau produsen (penyedia jasa) dan disertai pola pembelian ulang yang konsisten. Menurut Kotler dan Keller (2009) konsumen yang loyal dapat diukur melalui tiga hal, yaitu :

1. Rekomendasi positif dari mulut ke mulut (word of mouth). Merekomendasikan orang lain untuk membeli atau mereferensikan kepada orang lain.

2. Pembelian ulang (repeat purchasing). Seberapa sering melakukan pembelian ulang.

3. Penolakan terhadap perusahaan lain ( reject another). Menolak menggunakan produk atau lain atau menunjukan kekebalan terhadap tarikan dari pesaing.

Griffin (2003) mengemukakan keuntungan-keuntungan yang akan diperoleh perusahaan apabila memiliki konsumen yang loyal, antara lain :

1. Mengurangi biaya pemasaran, karena biaya untuk menarik pelanggan baru lebih mahal dibandingkan dengan biaya pengambil alihan pelanggan.

2. Mengurangi biaya transaksi, seperti negosiasi kontrak dan pemprosesan order.

3. Mengurangi biaya turn over pelanggan, karena pergantian pelanggan yang hilang lebih sedikit.

4. Meningkatkan penjualan silang yang akan memperbesar pangsa pasar perusahaan.

5. Word of mouth yang lebih positif dengan asumsi bahwa pelanggan yang loyal juga berarti mereka yang merasa puas.

6. Mengurangi biaya kegagalan, yang berarti pengurangan biaya pergantian, pengerjaan ulang, klaim garansi.

Menurut Kotler dan Keller (2007), loyalitas dapat dicapai melalui dua tahap, yaitu :

1. Perusahaan harus mempunyai kemampuan dalam memberikan kepuasan kepada konsumen agar konsumen mendapatkan suatu pengalaman yang postif.

2. Perusahaan harus mempunyai cara untuk mempertahankan hubungan yang lebih jauh dengan konsumennya agar konsumen ingin melakukan pembelian ulang.

Griffin, 2003 mengemukakan lima indikator yang bisa digunakan untuk mengukur loyalitas konsumen yaitu :

1. Mengatakan hal-hal positif mengenai produk.

2. Menyarankan orang lain untuk membeli produk.

3. Bersedia membayar dengan harga yang tinggi.

4. Bersedia melakukan pengulangan pembelian.

5. Bersedia untuk tidak akan berpindah ke merek lain.

Marconi (1993) menyebutkan faktor-faktor yang berpengaruh terhadap loyalitas adalah sebagai berikut: 
1. Nilai (harga dan kualitas), penggunaan suatu merek dalam waktu yang lama akan mengarahkan pada loyalitas, karena itu pihak perusahaan harus bertanggungjawab untuk menjaga merek tersebut. Perlu diperhatikan, pengurangan standar kualitas dari suatu merek akan mengecewakan konsumen bahkan konsumen yang paling loyal sekalipun begitu juga dengan perubahan harga. Karena itu pihak perusahaan harus mengontrol kualitas merek beserta harganya.

2. Citra (baik dari kepribadian yang dimilikinya dan reputasi dari merek tersebut), citra dari perusahaan dan merek diawali dengan kesadaran. Berdasarkan penelitian yang dilakukan ada korelasi antara kesadaran dan market share, sehingga dapat disimpulkan juga ada hubungan antara citra merek dengan market share. Produk yang memiliki citra yang baik akan dapat menimbulkan loyalitas konsumen pada merek.

3. Kenyamanan dan kemudahan untuk mendapatkan merek. Dalam situasi yang penuh tekanan dan permintaan pasar yang menuntut akan adanya kemudahan, pihak perusahaan dituntut untuk menyediakan produk yang nyaman dan mudah untuk didapatkan.

4. Kepuasan yang dirasakan oleh konsumen.

5. Pelayanan, dengan kualitas pelayanan yang baik yang ditawarkan oleh suatu merek dapat mempengaruhi loyalitas konsumen pada merek.

6. Garansi dan jaminan yang diberikan oleh merek.

Schiffman dan Kanuk (2004) juga menambahkan bahwa faktor-faktor yang mempengruhi loyalitas konsumen adalah kepuasan yang diterima oleh konsumen, peneriman keunggulan produk, keyakinan atau kepercayaan yang dimiliki seseorang terhadap produk serta keterikatan dengan produk atau perusahaan.

Berdasarkan teori di atas maka dalam penelitian ini akan melihat seberapa besar pengaruh variabel kepuasan, kepercayaan dan harga terhadap loyalitas.

\section{Satisfaction}

Kotler dan Keller (2007) memberikan definisi kepuasan sebagai fungsi dari seberapa sesuai nya harapan pembeli produk dengan kinerja yang di fikirkan pembeli atas produk tersebut. Westbrook dan reilly dalam Tjiptono (2008) memberikan definisi kepuasan sebagai respons emosional terhadap pengalamanpengalaman berkaitan dengan produk atau jasa tertentu yang di beli. Menurut Tjiptono (2008) bahwa dengan memperhatikan kualitas produk maka akan meningkatkan indeks kepuasan konsumen yang diukur dalam ukuran apapun. Secara lebih jauh, kepuasan sebagian besar dilihat sebagai satu bentuk dimensi dimana semakin tinggi kualitas produk yang dirasakan/diterima, maka semakin tinggi tingkat kepuasan yang terjadi. Menurut Julianto (2000), kepuasan merupakan suatu tingkat perasaan konsumen yang diperoleh setelah menikmati sesuatu, apabila dijabarkan kepuasan konsumen adalah perbedaan antara harapan konsumen dengan realisasi yang diberikan perusahaan dalam usaha memenuhi harapan konsumen apabila :

1. Nilai harapan = nilai persepsi, maka konsumen puas.

2. Nilai harapan $>$ nilai persepsi, maka konsumen puas.

3. Nilai harapan < nilai persepsi, maka konsumen tidak puas.

Berdasarkan definisi di atas, maka kepuasan konsumen adalah perbandingan antara harapan dengan persepsi konsumen terhadap produk atau jasa setelah produk atau 
jasa tersebut di konsumsi. Lupiyoadi (2001) menyebutkan terdapat beberapa faktor utama yang berkaitan dengan kepuasan konsumen, antara lain :

1. Kualitas produk, konsumen akan puas apabila hasil evaluasi mereka menunjukan bahwa produk yang mereka gunakan berkualitas. Produk dikatakan berkualitas bagi seseorang jika produk tersebut dapat memenuhi kebutuhannya.

2. Emosional, konsumen merasa puas ketika orang memuji dia karena menggunakan merek yang mahal.

3. Harga, produk yang mempnyai kualitas yang sama tetapi menetapkan harga yang relatif murah akan memberikan nilai yang lebih tinggi.

4. Biaya, konsumen yang tidak perlu mengeluarkan biaya tambahan atau tidak perlu membuang waktu untuk mendapatkan suatu produk atau jasa cenderung puas terhadap produk atau jasa tersebut.

Kepuasan dapat menciptakan konsep dasar bagi pemasaran dan dapat dipakai sebagai alat prediksi yang bagus untuk perilaku pembelian yang akan datang. Untuk meningkatkan kepuasan konsumen, suatu organisasi harus mengelola sumber daya nya. Jika hasil yang diterima konsumen dari suatu produk sesuai dengan keinginannya, maka kepuasan dapat tercapai. Sepuluh hal yang dapat dilakukan untuk meningkatkan kepuasan konsumen menurut Gerson (2001), yaitu :

1. Membangun mutu dalam produk dan jasa.

2. Mengembangkan gairah fokus konsumen.

3. Mengamati kosumen secara akrab.

4. Setiap orang bekerja untuk konsumen.

5. Melatih staff yang ada.

6. Memberdayakan konsumen.

7. Terus menerus mengukur kepuasan konsumen.

8. Memberikan pengakuan dan imbalan, baik kepada konsumen atau kepada karyawan.

9. Mencari cara baru atau strategi baru.

10. Membuat produk menjadi lebih baik.

Indikator dari variabel Kepuasan Konsumen (Elitan, 1999,), yaitu :

1. Tidak ada keluhan atau keluhan yang teratasi

2. Perasaan puas pelanggan pada keseluruhan produk

3. Kesesuaian dengan expectasi / harapan pelanggan

4. Harapan pelanggan yang terlampaui

\section{Trust}

Trust atau kepercayaan adalah tingkat kepercayaan diri dimana anggota golongan yang lain akan bertindak sesuai yang telah di fikirkan (Hart and Saunders, 1997). Kemudian Rousseau et. al., 1998, menyatakan bahwa kepercayaan adalah keinginan untuk menerima kekurangan dengan pemikiran yang positif terhadap perilaku ataupun ketertarikan pada orang lain atau produk.

Menurut Mowen dan Minor (2002), terdapat 3 jenis kepercayaan, yaitu :

1. Kepercayaan atribut objek, kepercayaan ini menghubungkan sebuah atribut dengan objek, seperti seseorang, barang atau jasa. Dimana melalui atribut objek, konsumen menyatkan apa yang diketahui tentang sesuatu dalam hal variasi atributnya. 
2. Kepercayaan manfaat atribut, merupakan persepsi konsumen tentang seberapa jauh atribut tertentu menghasilkan dan memberikan manfaat tertentu.

3. Kepercayaan manfaat objek, merupakan persepsi konsumen tentang sejauh mana produk atau jasa tertentu akan memberikan manfaat tertentu.

Nursatyo (2003) yang termasuk variabel kepercayaan yaitu :

1. Kredibilitas, terkait dengan kemampuan perusahaan untuk memenuhi semua kewajibannya, perusahaan yang berhasil memenuhi semua kewajibannya seharusnya akan menimbulkan kemauan membali untuk melanjutkan hubungannya.

2. Kepedulian, terkait dengan kemauan perusahaan untuk mempedulikan nasib konsumen.Dapat diandalkan, menimbulkan kemauan konsumen untuk mengandalkan.

Menurut Ramadania (2003:39), adapun indikator Kepercayaan adalah sebagai berikut :

1. Reputasi yang dimiliki produk

2. Keamanan dan kenyamanan dalam menggunakan produk

3. Manfaat yang ada di produk.

\section{Price}

Harga adalah nilai suatu barang dan jasa yang diukur dengan sejumlah uang. Berdasarkan nilai tersebut seseorang atau perusahaan bersedia melepaskan barang atau jasa yang dimiliki kepada pihak lain. Dalam perusahaan harga suatu barang atau jasa merupakan penentuan bagi permintaan pasar. Harga dapat mempengaruhi posisi persaingan perusahaan. Keputusan tentang harga tidak pernah boleh dilakukan secara kebetulan. Pada produk yang umum, penurunan harga dapat menaikkan penjualan, sedangkan pada produk yang membawa citra bergengsi, kenaikan harga akan menaikkan penjualan karena produk dengan harga tinggi akan menunjukan prestasi seseorang.

Menurut Kotler dan Amstrong (2001), harga adalah sejumlah uang yang dibebankan atas suatu produk, atau jumlah dari nilai yang ditukar konsumen atas manfaat - manfaat karena memiliki atau menggunakan produk tersebut. Sementara menurut Dharmesta dan Irawan (2005), harga adalah sejumlah uang (ditambah beberapa produk kalau mungkin) yang dibutuhkan untuk mendapatkan sejumlah kombinasi dari produk dan pelayanannya. Harga merupakan salah satu penentu pemilihan produk yang nantinya akan berpengaruh terhadap minat pembelian. Bila suatu produk mengharuskan konsumen mengeluarkan biaya yang lebih besar dibandingkan dengan manfaat yang diterima, maka yang terjadi adalah bahwa produk tersebut memiliki nilai negatif. Sebaliknya, apabila konsumen menganggap bahwa manfaat yang diterima lebih besar, maka yang terjadi adalah produk tersebut memiliki nilai yang positif. W.J Stanton (1998) adapun indikator harga sebagai berikut :

1. Keterjangkauan harga

2. Kesesuaian harga dengan kualitas produk

3. Daya saing harga

4. Kesesuaian harga dengan manfaat 


\section{Hubungan kepuasan Terhadap Loyalitas Konsumen Pada Green Product}

Perusahaan harus mampu untuk meningkatkan kepuasan konsumen serta mempertahankan kepuasan konsumen tesebut guna menciptakan loyalitas konsumen terhadap suatu produk. Menurut Kotler dan Keller (2007), kepuasan merupakan hasil evaluasi yang dilakukan konsumen dengan memberikan penilaian terhadap kinerja produk atau merek tertentu dengan harapan yang diinginkannya.

Bila kinerja sesuai dengan harapan konsumen maka konsumen akan merasa puas. Dengan adanya kepuasan tersebut maka konsumen akan membeli ulang produk tersebut secara konsisten sepanjang waktu, sehingga terciptalah loyalitas konsumen terhadap produk atau merek tersebut.

Kotler dan Keller (2009) menyatakan ciri-ciri konsumen yang merasa puas adalah sebagai berikut :

1. Loyal terhadap produk, konsumen yang puas cenderung loyal dimana mereka akan membeli ulang dari produsen yang sama.

2. Adanya komunikasi dari mulut ke mulut yang sifatnya positif, komunikasi dari mulut ke mulut yang sifatnya positif yaitu rekomendasi kepada calon konsumen lain dan mengatakan hal-hal yang baik mngenai produk dan perusahaan.

3. Perusahaan menjadi pertimbangan utama ketika membeli merek lain, ketika konsumen igin membeli produk yang lain maka perusahaan yang telah memberika kepuasan kepadanya akan menjadi pertimbangan yang utama.

\section{Hubungan kepercayaan Terhadap Loyalitas Konsumen Pada Green Product}

Kepercayaan diperlukan dalam menjalin hubungan antara perusahaan dan konsumen, dengan keprcayaan dapat menimbulkan loyakitas konsumen terhadap produk atau jasa. menurut Tjiptono (2008) dalam menjalin hubungan yang baik kepercayaan merupakan faktor penting yang mempengaruhi sebuah komitmen. Apabila tidak ada kepercayaan maka tidak akan ada komitmen yang tercipta. Dengan adanya komitmen mampu menciptakan konsumen yang loyal karena telah mempercayai kinerja atau kemampuan produk dan perusahaan tertentu.

Menurut Morgan dan Hunt (1994) kepercayaan dan komitmen merupakan kunci keberhasilan dari suatu hubungan antar perusahaan dengan konsumennya. Dengan adanya kesediaan konsumen untuk mempercayai kemampuan sebuah produk atau brand akan mempunyai hubungan yang positif dengan niat melakukan pembelian ulang dan akan melakukan intensitas pembelian ulang yang dapat mempengaruhi loyalitas konsumen.

\section{Hubungan Harga Terhadap Loyalitas Konsumen Pada Green Product}

Penetapan harga yang tepat terhadap suatu produk atau jasa merupakan suatu hal yang penting dilakukan perusahaan dalam membangun loyalitas konsumen. Ferdinand (2006) menjelaskan bahwa harga merupakan salah satu variabel penting dalam pemasaran, dimana harga dapat mempengaruhi pelanggan dalam mengambil keputusan untuk membeli suatu produk, karena berbagai alasan. Alasan ekonomis akan menunjukkan bahwa harga yang rendah atau harga yang selalu berkompetisi merupakan salah satu pemicu penting untuk meningkatkan kinerja pemasaran, tetapi alasan psikologis dapat menunjukkan bahwa harga justru merupakan indikator kualitas dan karena itu dirancang sebagai salah satu instrumen penjualan sekaligus sebagai instrumen kompetisi yang menentukan. 


\section{Model Penelitian}

Kerangka analisis berikut ini menunjukan bagaimana bentuk hubungan antar variabel yang akan diteliti dalam kajian green product terhadap loyalitas konsumen.

\section{Gambar 1 Model Penelitian}

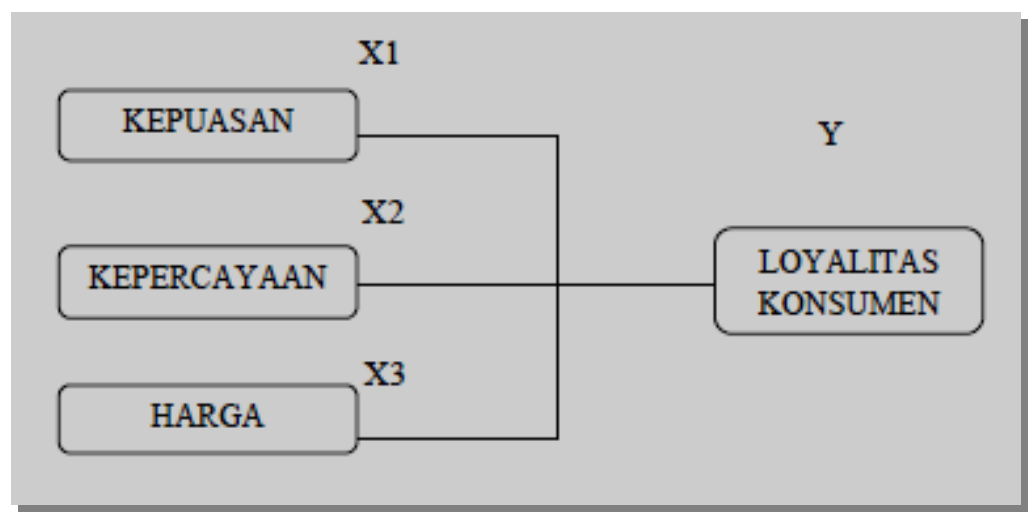

METODE PENELITIAN

\section{Jenis Penelitian}

Penelitian ini merupakan jenis penelitian survey yang bertujuan untuk menggambarkan, menjelaskan dan memaparkan suatu fenomena tertentu yang terjadi di lapangan melalui penyebaran kuesioner dan observasi langsung. Jenis data yang digunakan adalah data primer yang diperoleh melalui penyebaran kuesioner. Metode yang akan dipergunakan pada penelitian ini adalah metode kuantitatif. Metoda kuantitatif yaitu data yang berbentuk angka atau data kualitatif yang diangkakan (Sugiyono, 2004). Proses penelitian kuantitatif bersifat deduktif, dimana untuk menjawab rumusan masalah digunakan konsep atau teori sehingga dapat dirumuskan hipotesis. Hal ini bertujuan untuk memperoleh fakta-fakta yang ada serta mencari keterangan yang aktual yang dapat mendukung penelitian ini dalam mengidentifikasi pengaruh kepuasan, kepercayaan, dan harga terhadap loyalitas konsumen .

\section{Metode Pengambilan Sampel}

Populasi dalam penelitian ini adalah semua konsumen yang telah menggunakan lampu hemat energi di Kelurahan Kandang, Kota Bengkulu. Setelah populasi sasaran ditentukan maka langkah selanjutnya adalah menentukan tekhnik pengambilan sampel dan kemudian menentukan jumlah sampel yang akan diambil ( Ferdinand, 2006 ). Karena jumlah populasi dalam penelitian ini tidak dapat diketahui dengan pasti, maka digunakan metode pengumpulan data sesuai dengan yang dinyatakan oleh Roscoe dalam Sugiyono (2005:102) yang mengusulkan aturan ukuran sampel yang layak dalam penelitian antara 30 sampai dengan 500 dan dalam penelitian multivariat (termasuk analisis regresi berganda), ukuran sampel sebaiknya 10 kali atau lebih besar dari jumlah variabel dalam studi. Dalam penelitian ini terdapat 4 variabel yang terdiri dari variabel bebas dan variabel terikat. Oleh karena itu, berdasarkan pendapat Roscoe sampel minimal untuk 
penelitian ini adalah 40 responden. Dengan pertimbangan agar tingkat keakuratan data yang dihasilkan dari populasi jauh lebih baik, maka peneliti menetapkan sebanyak 120 responden. Dalam penelitian ini, peneliti menggunakan Teknik Purposive Sampling, yang mana tidak semua orang memiliki kesempatan yang sama. Purposive Sampling adalah teknik penentuan sampel dengan pertimbangan tertentu (Sugiyono, 2011:68).

\section{HASIL PENELITIAN DAN PEMBAHASAN}

\section{Karakteristik Responden}

Berdasarkan hasil penelitian kepada 102 orang responden melalui kuesioner yang telah disebarkan didapat gambaran karakteristik responden dalam tabel berikut:

Tabel 1

Karakteristik responden

\begin{tabular}{|c|c|c|c|}
\hline No & Karakteristik responden & Jumlah Orang & Persentase \\
\hline \multirow[t]{3}{*}{1} & Berumah tangga & & \\
\hline & Sudah Berumah tangga & 89 & 87,2 \\
\hline & Belum berumah tangga & 13 & 12,8 \\
\hline \multirow[t]{4}{*}{2} & Usia & & \\
\hline & $20-34$ tahun & 48 & 47,1 \\
\hline & $35-50$ tahun & 39 & 38,2 \\
\hline & $>50$ tahun & 15 & 14,7 \\
\hline \multirow[t]{3}{*}{3} & Sudah bekerja & & \\
\hline & Sudah & 84 & 82,4 \\
\hline & Belum & 18 & 17,6 \\
\hline \multirow[t]{4}{*}{4} & Pendapatan perbulan & & \\
\hline & $<1$ juta & 5 & 5,00 \\
\hline & 1 juta - 2 juta & 43 & 42,1 \\
\hline & $>2$ juta & 54 & 52,9 \\
\hline \multirow[t]{4}{*}{5} & Kepemilikan lampu hemat energi & & \\
\hline & 1 unit LHE & 5 & 5,00 \\
\hline & 2 unit LHE & 18 & 17,6 \\
\hline & $>2$ unit LHE & 79 & 77,4 \\
\hline \multirow[t]{5}{*}{6} & Merek lampu hemat energi & & \\
\hline & 1. HORI & 12 & 9,2 \\
\hline & 2. OSRAM & 23 & 17,7 \\
\hline & 3. PHILIPS & 67 & 51,5 \\
\hline & 4. SINYOKU & 28 & 21,6 \\
\hline
\end{tabular}

Sumber : Hasil Penelitian 2014 


\section{Hasil Analisis Regresi Linear Berganda}

Analisis Regresi pada dasarnya adalah studi mengenai ketergantungan variabel dependen (terikat) dengan satu atau lebih variabel independen (variabel penjelas/bebas) dengan tujuan untuk mengestimasi dan memprediksi rata-rata populasi atau nilai-nilai variabel dependen berdasarkan nilai variabel independen yang diketahui (Ghozali, 2005).

Tabel 2

Coefficients ${ }^{\mathrm{a}}$

\begin{tabular}{|c|c|c|c|c|c|c|c|}
\hline \multirow[t]{2}{*}{ Model } & \multicolumn{2}{|c|}{$\begin{array}{c}\text { Unstandardized } \\
\text { Coefficients }\end{array}$} & \multirow{2}{*}{$\begin{array}{c}\begin{array}{c}\text { Standardized } \\
\text { Coefficients }\end{array} \\
\text { Beta }\end{array}$} & \multirow[t]{2}{*}{$\mathrm{t}$} & \multirow[t]{2}{*}{ Sig. } & \multicolumn{2}{|c|}{$\begin{array}{c}\text { Collinearity } \\
\text { Statistics }\end{array}$} \\
\hline & B & $\begin{array}{l}\text { Std. } \\
\text { Error }\end{array}$ & & & & Tolerance & VIF \\
\hline 1 (Constant) & 4.450 & 1.509 & & 2.949 & .004 & & \\
\hline $\mathrm{x} 1$ & .093 & .079 & .110 & 1.182 & .240 & .649 & 1.542 \\
\hline $\mathrm{X} 2$ & .317 & .082 & .339 & 3.855 & .000 & .724 & 1.381 \\
\hline X3 & .386 & .087 & .384 & 4.420 & .000 & .745 & 1.343 \\
\hline
\end{tabular}

a.Dependent Variable: $Y$

$\mathrm{Y}=4,450+0,093 \mathrm{X} 1+0,317 \mathrm{X} 2+0,386 \mathrm{X} 3$

Interpretasi hasil koefisien regresi pada persamaan diatas adalah :

1. Koefisien konstanta sebesar 4.450 dan bertanda positif menandakan bahwa ada atau tidak ada variabel X1, X2 dan X3 maka loyalitas konsumen terhadap produk lampu hemat energi tetap sebesar 4,450.

2. Koefisien regresi variabel Kepuasan (X1) terhadap loyalitas konsumen produk lampu hemat energi pada masyarakat Bengkulu diperoleh sebesar 0,093 dengan tingkat signifikan 0,240 yang lebih besar dari 0,05 dimana hal tersebut menunjukan bahwa kepuasan berpengaruh positif terhadap loyalitas konsumen tetapi tidak signifikan. Jika variabel lain nilainya tetap dan X1 mengalami kenaikan 1 satuan, maka Y akan mengalami kenaikan sebesar 0,093.

3. Koefisien regresi variabel Kepercayaan (X2) terhadap loyalitas konsumen produk lampu hemat energi pada masyrakaat Bengkulu diperoleh sebesar 0,317 dengan tingkat signifikan 0,000 yang lebih kecil dari 0,05 dimana hal tersebut menunjukan bahwa kepercayaan berpengaruh positif terhadap loyalitas konsumen, dimana variansi perubahan loyalitas konsumen yang dipengaruhi oleh kepercayaan sebesar 0,317 . Jika variabel lain nilainya tetap dan X2 mengalami kenaikan 1 satuan, maka Y akan mengalami kenaikan sebesar 0,317 .

4. Koefisien regresi variabel Harga (X3) terhadap loyalitas konsumen produk lampu hemat energi pada masyrakaat Bengkulu diperoleh sebesar 0,386 dengan tingkat signifikan 0,000 yang lebih kecil dari 0,05 dimana hal tersebut menunjukan bahwa harga berpengaruh positif terhadap loyalitas konsumen, dimana variansi perubahan loyalitas konsumen yang dipengaruhi oleh harga sebesar 0,386 . Jika variabel lain nilainya tetap dan X3 mengalami kenaikan 1 satuan, maka Y akan mengalami kenaikan sebesar 0,386 . 
Tabel 3

Model Summary

\begin{tabular}{|c|c|c|c|c|l|}
\hline Model & $\mathrm{R}$ & R Square & Adjusted R Square & $\begin{array}{l}\text { Std. Error of the } \\
\text { Estimate }\end{array}$ & Durbin-Watson \\
\hline 1 & $.671 \mathrm{a}$ & .450 & .433 & 1.959 & 2.260 \\
\hline
\end{tabular}

a. Predictors: (Constant), X3, X2, $x 1$

b. Dependent Variable: $Y$

Berdasarkan hasil perhitungan dengan menggunakan SPSS 16.0 didapat nilai koefisien determinasi berganda (R2) sebesar 0,450. Hal ini menunjukan bahwa perubahan tingkat loyalitas konsumen dipengaruhi hanya sebesar $45 \%$ oleh vriabel kepuasan, kepercayaan dan harga. Maka dapat disimpulkan bahwa ketiga variabel tersebut tidak begitu dominan mempengaruhi loyalitas konsumen.

\section{Uji Simultan ( Uji F)}

Uji F dilakukan untuk mengetahui pengaruh variabel bebas secara bersamasama terhadap variabel terikat. Jika Fsig $\geq(\alpha=0,05)$ maka Ho diterima dan Ha ditolak, berarti variabel pengaruh $(\mathrm{X})$ secara bersama tidak berpengaruh terhadap variabel terpengaruh (Y). Jika Fsig $\leq(\alpha=0,05)$ maka Ho ditolak dan Ha diterima, berarti variabel pengaruh $(X)$ secara bersama mempunyai pengaruh terhadap variabel terpengaruh $(\mathrm{Y})$.

Tabel 4

ANOVA $^{b}$

\begin{tabular}{|c|r|r|r|r|l|}
\hline Model & Sum of Squares & Df & Square & \multicolumn{1}{|c|}{ F } & Sig. \\
\hline 1 Regression & 307.874 & 3 & 102.625 & 26.750 & $.000 \mathrm{a}$ \\
Residual & 375.969 & 98 & 3.836 & & \\
Total & 683.843 & 101 & & & \\
\hline
\end{tabular}

a. Predictors: (Constant), $X 3, X 2, \times 1$

b. Dependent Variable: $Y$

Dari hasil perhitungan uji $\mathrm{F}$ yang menguji pengaruh secara bersama-sama dapat diketahui $\mathrm{F}$ hitung untuk variabel kepuasan, kepercayaan, harga dan loyalitas adalah sebesar 26.750 dengan nilai signifikan $0,000 \leq 0,05$ maka hal ini mengindikasikan bahwa Kepuasan, Kepercayaan, Harga dan Loyalitas secara simultan mempunyai pengaruh positif terhadap loyalitas konsumen.

\section{Uji Parsial (Uji T)}

Uji t pada dasarnya menunjukan seberapa jauh pengaruh satu variabel bebas secara individual dalam menerangkan variabel terikat. Jika tsig $\geq(\alpha=0,05)$ maka Ho diterima dan Ha ditolak, berarti variabel bebas $(X)$ secara parsial tidak berpengaruh terhadap variabel terikat (Y). Jika tsig $\leq(\alpha=0,05)$ maka Ho ditolak dan Ha diterima, berarti variabel bebas $(\mathrm{X})$ secara parsial mempunyai pengaruh terhadap variabel terikat (Y). Berdasarkan tabel 2 dapat dilihat variabel kepuasan memberikan nilai signifikan 0,240>0,05 yang menunjukan variabel kepuasan secara parsial berpengaruh terhadap loyalitas konsumen namun tidak signifikan. Pada variabel Kepercayaan memberikan nilai Signifikan 0,000 $<0,05$ yang menunjukan bahwa 
variabel Kepercayaan secara parsial berpengaruh terhadap loyalitas konsumen. Pada variabel Harga memberikan nilai signifikan 0,000 $<0,05$ yang menunjukan bahwa variabel Harga secara parsial berpengaruh terhadap loyalitas konsumen.

\section{Pembahasan}

Dalam penelitian ini terdapat tiga variabel bebas yaitu kepuasan, kepercayaan dan harga yang mempengaruhi variabel terikat yaitu loyalitas. Penelitian ini dilakukan untuk mengetahui apakah ketiga variabel tersebut memiliki pengaruh terhadap loyalitas konsumen produk lampu hemat energi. Berdasarkaan hasil pengolahan data menggunakan persamaan regresi linear berganda diperoleh bahwa variabel kepercayaan (X2), dan harga (X3) mempunyai pengaruh positif terhadap loyalitas konsumen produk lampu hemat energi. Hal ini didukung dari hasil perhitungan koefisien t hitung untuk variabel Kepercayaan (X2) sebesar 3.885 dengan nilai signifikan sebesar 0.000 , nilai signifikan yang lebih kecil dari 0,05 . Hal ini mengindikasikan bahwa semakin tinggi tingkat kepercayaan konsumen terhadap produk tertentu maka akan semakin tinggi pula tingkat loyalitas konsumen terhadap produk tersebut. Dimana konsumen yang memiliki kepercayaan terhadap suatu produk akan terus menggunakan produk yang sama.

Hasil perhitungan dengan menggunakan persamaan regresi linear berganda menunjukan bahwa Harga (X3) juga memiliki pengaruh positif terhadap loyalitas konsumen. Jika dilihat dari hasil perhitungan koefisien t hitung sebesar 4.420 dengan signifikan sebesar 0.000 lebih kecil dari 0,05. Hal ini menunjukan bahwa harga mampu mempengaruhi konsumen untuk menjadi loyal terhadap produk. Harga lampu hemat energi telah menciptakan kesan positif pada konsumen. Berdasarkan hasil perhitungan dengan menggunakan persamaaan regresi linear berganda menunjukan bahwa variabel Kepuasan (X1) koefisien t hitung sebesar 1.182 dengan signifikan sebesar 0.240 lebih besar dari 0,05. Hal ini menunjukan bahw variabel kepuasan berpengaruh terhadap loyalitas konsumen namun tidak signifikan.

Keberhasilan perusahaan tidak hanya berfokus pada kepuasan konsumen saja, karena tidak ada jaminan bahwa konsumen yang puas akan membeli ulang dari suatu perusahaan. Perusahaan hendaknya mampu menjadikan kepuasan konsumen sebagai tujuan awal guna pencapaian loyalitas konsumen, dimana Loyalitas pelanggan adalah kesetiaan pelanggan akan suatu barang atau jasa dengan melakukan pembelian ulang barang atau jasa tersebut secara terus menerus. Konsumen akan loyal terhadap perusahaan jika keinginan dan kebutuhannya tercapai. Selanjutnya hanya perusahaan yang berwawasan pada konsumen yang akan tetap hidup karena dapat menciptakan nilai yang lebih unggul dibanding pesaing-pesaingnya. Tingkat pelayanan yang dapat memberikan kepuasan pada konsumen akan membangun kesetiaan konsumen dan akhirnya dapat menciptakan hubungan yang erat antara konsumen dan perusahaan.

\section{KESIMPULAN}

\section{Kesimpulan}

Dari hasil penelitian mengenai pengaruh Kepuasan, Kepercayaan, dan Harga terhadap Loyalitas Konsumen pada Green Product, maka diperoleh kesimpulan : 
1. Harga merupakan faktor terbesar yang mempengaruhi tingkat loyalitas konsumen dalam penelitian ini, harga yang diberikan perusahaan terhadap produk lampu hemat energi memberikan respon positif dari konsumen sehingga dapat menimbulkan loyalitas konsumen yang tinggi terhadap produk lampu hemat energi.

2. Kepercayaan merupakan faktor terbesar kedua yang mempengaruhi loyalitas konsumen dalam penelitian ini, komitmen perusahaan yang menggunakan bahan yang tidak berbahaya dan tidak menghabiskan banyak energi telah meningkatkan kepercayaan konsumen akan produk lampu hemat energi yang mereka gunakan.

3. Kepuasan merupakan variabel yang memiliki tingkat pengaruh paling rendah terhadap loyalitas konsumen. Belum terciptanya kepuasan konsumen akan penggunaan produk lampu hemat energi di sebabkan dari kenyaman dalam menggunakan produk lampu hemat energi belum sesuai dengan yang apa diinginkan oleh konsumen.

4. Kepuasan, kepercayaan dan harga secara bersama-sama berpengaruh terhadap loyalitas konsumen yang ditunjukan dari hasil $\mathrm{f}$ hitung sebesar 26.750 dengaan nilai signifikan 0.000 .

\section{Saran}

Dari hasil penelitian ini mengenai variabel Kepuasan, Kepercayaan dan Harga terhadap Loyalitas Konsumen lampu hemat energi maka saran yang dapat diberikan peneliti adalah :

1. Berdasarkan wawancara terhadap 12 orang responden mereka menyatakan bahwa tidak terpenuhinya kepuasan mereka karena sulitnya untuk melakukan klaim garansi, klaim hanya bisa dilakukan di tempat resmi distibutor lampu hemat energi dan tidak bisa dilakukan di toko tempat pembelian lampu hemat energi. Seharusnya pihak distributor memberikan kewewenangan bagi toko yang menyediakan lampu hemat energi untuk menerima klaim garansi guna memudahkan konsumen dalam melakukan klaim. agar tercapainya loyalitas konsumen pada penggunaan produk lampu hemat energi.

2. Konsumen belum merasa aman dalam penggunaan produk lampu hemat energi. Seharusnya perusahaan lebih mementingkan keamanan konsumen dalam penggunaan produknya, dengan menggunakan bahan yang tidak berbahaya dan tingkat keamanan yang baik dalam penggunan produk lampu hemat energi.

\section{DAFTAR PUSTAKA}

Dharmesta B. Swastha dan Irawan. 2005. Manajemen Pemasaran Modern. Edisi 2, Liberty. Yogyakarta.

Ellitan, Lena. 1999. Membangun Loyalitas melalui Costumer Satisfaction dan Costumer Orientde. Kompak.

Ferdinand, Augusty. 2006. Struktural Equation Modeling (SEM) Dalam Penelitian Manajemen.Semarang: Universitas Diponegoro.

Gerson, R,F, 2001. Mengukur Kepuasan Pelanggan, PPM, Jakarta.

Ghozali, Imam. 2005. Aplikasi Analisis Multivariate dengan Program SPSS. Semarang: BP Universitas Diponegoro. Semarang.

Griffin. 2003. Customer Loyalty, Erlangga, Jakarta. 
Hart, P. \& Saunders, C. 1997. Power and Trust: Critical Factors in the Adoption and use of Electronic Data Interchange. Organizational Science (8:1), pp. 23-42.

Http://www.elektroindonesia.com

Julianto, Heppy.2000. Mengukur Kepuasan Pelanggan. Manajemen, pp34-35.

Kasali,rhenald. 2009. Sembilan Fenomena Bisnis, manajemen study society MSS, FEUI official site.

Kotler, P. dan Keller, K.L.,2007, Manajemen Pemasaran, Cet 2, Edisi 12, Jilid 1, Alih bahasa: Benyamin Molan. Penerbit PT INDEKS.

Kotler \& Keller. 2009. Marketing Management, Penerjemah Bob Sabran, Edisi Ketiga Belas, Erlangga, Jakarta.

Kotler, Philip, dan Gary, Amstrong. 2001. Prinsip-Prinsip Pemasaran. Penerjemah Imam Nurmawan. Jakarta : Penerbit Salemba Empat.

Kotler, Philip Dan Kevin Lane Keller. 2007. Manajemen Pemasaran. Edisi Kedua Belas. Indeks : Jakarta.

Lanasier, E.V. 2002. Perilaku Konsumen Hijau Indonesia: Tinjauan Sudut Demografi dan Psikografi, Media Riset Bisnis dan Manajemen, Volume 2, Nomor 2, PP.8911, Jakarta.

Lupiyoadi, Rambat. 2001. Manajemen Pemasaran Jasa; Teori dan Aplikasi, Edisi Pertama, PT. Salemba Empat, Jakarta.

Marconi, Joe. 1993. Beyond Branding. Chicago: Probus Publishing Company

Mowen dan Minor. 2002. Perilaku Konsumen, Penerbit Erlangga,Yakarta.

Morgan, R. M. and Hunt, S. D. 1994. The Commitment-Trust Theory of Relationship Marketing, Journal of Marketing, 58 (July):20-38.

Nasution, 2005, Total Quality Management, PT Gramedia Pustaka Utama:Jakarta.

Nugrahadi, EW. 2002. Pertanian Orgaik Sebagai Alternatif Teknologi Dalam Upaya Menghasilkan Produk Hijau. IPB. Bogor.

Nursatyo Heri, Bowo, 2003, Analisis Pengaruh Komitmen Untuk Mencapai Hubungan Jangka Panjang, Jurnal Sains Pemasaran Indonesia, Volume II, Nomor 1, p. 85-92

Ottman, J.A. Stafford E.\& R. Hartman. C.L. 2006 Green Marketing Myopia :Ways to Improve consumer Appeal for Environmentally Preferable Products. Environment Volume 48, Number 5 pp 22-36 Heldref Publications, 2006.

Ramadania. 2003. Kepercayaan dan Komitmen Sebagai Perantara Kunci Relationship Marketing Dalam Membangun Loyalitas. Universitas Tanjungpura. Pontianak. Tesis.

Rousseau, D.M., S. Sitkin, R.S. Burt and C. Camerer 1998, „Not so different after all: A cross-discipline view of trust", Academy of Management Review, 23, 393404.

Schiffman, leon. And Kanuk, Leslie Lazar. 2004. Perilaku Konsumen (edisi ketujuh). PT. Indeks, Jakarta.

Sugiyono. 2004. Metode Penelitian Bisnis, Cetakan keenam,CV Alfabeta, Bandung.

Sugiyono, Prof. Dr, 2005. Metodologi Penelitian Bisnis. Bandung: Alfabeta.

Sugiyono. 2011. Statistika untuk Penelitian. Bandung: Alfabeta.

Tjiptono, Fandy. 2000. Perspektif Manajemen dan Pemasaran Kontemporer, Edisi 1, Yogyakarta, Andi.

Tjiptono, F. 2008. “Strategi Pemasaran”, Edisi III, Yogyakarta, Andi.

W.J, Stanton. 1998. "Prinsip Pemasaran”, erlangga, edisi ketujuh jilid 1, Jakarta. 